\title{
FENOMENA FISIKA DALAM MENGEMBANGKAN KETERAMPILAN SAINS ANAK USIA DINI
}

\author{
Hana Yunansah ${ }^{1}$
}

\begin{abstract}
ABSTRAK
Sains sebagai suatu konsep mendasar perlu dibelajarkan kepada anak sejak usia dini. Pengenalan sains pada anak usia dini dapat dilakukan dengan berbagai cara, salah satunya melalui pengamatan fenomena fisika. Melalui pengenalan sains pada anak usia dini dapat dikembangkan keterampilan sains anak. Beberapa keterampilan sains yang dapat dilatih dan dikembangkan pada anak usia dini seperti keterampilan mengamati, mengelompokkan, menggunakan angka atau bilangan (menghitung), memprediksi, melakukan eksperimen, dan mengomunikasikan. Pemilihan fenomena fisika yang sesuai dikaitkan dengan pengembangan keterampilan sains anak akan membuat pembelajaran menjadi lebih bermakna.

Kata Kunci: Fenomena Fisika, Keterampilan Sains, Anak Usia Dini
\end{abstract}

\section{A. PENDAHULUAN}

Keberhasilan para pelajar Indonesia dalam ajang perlombaan tingkat internasional tidak serta merta menggambarkan kondisi pembelajaran sesungguhnya. Hasil studi The Third International Mathematics and Science Study (TIMSS) tahun 2003 menunjukkan bahwa kemampuan sains siswa (SMP) Indonesia hanya berada pada peringkat ke-37 dari 46 negara. Kenyataan ini memberikan gambaran pencapaian mutu pendidikan nasional secara umum, yang juga masih jauh dari standar mutu yang diharapkan. Pembelajaran kerap kali lebih menekankan pada tuntutan akan hasil akhir yang diperoleh siswa, dan melupakan bagaimana proses yang dijalani. Liliasari (1996) mengungkapkan bahwa rendahnya penguasaan konsep IPA (sains) disebabkan oleh penggunaan pola pikir yang rendah pada pembentukan sistem konseptual sains.

Pembentukan sistem konseptual IPA (sains) tentu tidak dimulai ketika siswa memasuki jenjang pendidikan di sekolah lanjutan, melainkan sejak ia duduk di bangku pendidikan dasar, lebih khusus dalam pendidikan anak usia dini. Meskipun secara eksplisit ilmu sains tidak dicantumkan dalam kurikulum pendidikan taman kanak-kanak (TK), namun bukan tidak dibelajarkan pada anak. Bila dikaitkan dengan implementasi Kurikulum 2013, di mana pembelajaran pada anak jenjang usia sekolah dasar diterapkan secara tematik integrated melalui pendekatan saintifik, maka pengenalan konsep sains tentu menjadi esensial. Tentu saja pembelajaran dirancang agar sesuai dengan karakteristik usia siswa TK. Suyanto (2006) mengemukakan bahwa "pengenalan sains untuk anak TK jika dilakukan dengan benar akan mengembangkan secara bertahap kemampuan berpikir logis yang belum dimiliki anak". Kemampuan berpikir logis ini akan membawa nalar anak untuk terbiasa melakukan kegiatan sains secara terstruktur dan sistematis. Lebih lanjut, melalui pengenalan sains pada anak usia dini dapat dikembangkan keterampilan

${ }^{1}$ Dosen UPI Kampus Cibiru 
sains anak. Keterampilan sains ini penting untuk dikembangkan sejak anak duduk di bangku TK, dan ini akan menjadi bekal bagi mereka ketika memasuki jenjang pendidikan yang lebih tinggi.

Pelatihan dan pengembangan keterampilan sains pada anak usia dini dapat dilakukan melalui berbagai kegiatan; salah satunya melalui fenomena. Terdapat banyak fenomena alam, khususnya fenomena fisika yang dapat kita jadikan referensi untuk membelajarkan sains pada anak usia dini dan mengembangkan keterampilan sains mereka. Pengemasan yang menarik akan membuat konsep dan fenomena sains memberikan pengalaman yang tidak saja berkesan bagi anak, tetapi juga menjadi wahana perolehan pengetahuan secara tidak langsung. Tulisan ini mencoba mengupas mengenai fenomena fisika dalam mengembangkan keterampilan sains pada anak usia dini.

\section{B. PEMBAHASAN}

\section{Karakteristik Anak Usia Dini}

Menurut Undang-Undang No. 20 Tahun 2003 tentang Sistem Pendidikan Nasional, usia anak yang termasuk kategori anak usia dini didefinisikan sebagai anak pada rentang usia nol hingga enam tahun. Berdasarkan tingkatan pendidikan, anak usia dini dikategorikan sebagai anak yang memiliki periode masa pendidikan sebelum memasuki jenjang pendidikan dasar. Hasil-hasil riset di bidang psikologi dan neurosains menunjukkan bahwa masa usia dini merupakan masa golden ages atau periode emas bagi anak. Suyadi (2010) mengemukakan bahwa pada periode emas, yakni rentang usia nol hingga enam tahun, otak anak mengalami perkembangan yang sangat pesat. Terlebih lagi pada masa usia nol hingga empat tahun merupakan masa-masa yang paling menentukan. Otak merupakan hardware terpenting dalam tubuh manusia, di mana otak juga merupakan kunci utama dalam pembentukan kecerdasan anak. Pada rentang usia nol hingga enam tahun, otak mengalami perkembangan jaringan hingga mencapai 80 persen, sedangkan sisanya $(20 \%)$, perkembangan jaringan otak terjadi pada rentang usia di atas enam tahun hingga dewasa.

Bila melihat kenyataan tersebut, maka penanaman pengetahuan (sains) yang paling tepat adalah dilakukan pada rentang usia nol hingga enam tahun, ketika perkembangan jaringan otak paling pesat. Hal ini sesuai dengan pendapat Maria Montessori bahwa anak pada rentang usia tersebut mengalami periode absorbend mind. Anak pada rentang usia ini menyerap segala informasi apapun yang ia terima melalui inderanya. Montessori mengibaratkan otak anak pada rentang usia ini seperti spons yang mampu menyerap apapun yang ada di sekitarnya. Peristiwa ini terjadi hanya sekali seumur hidup; dan itu terjadi pada masa usia nol hingga enam tahun. Periode inilah yang menjadi "kunci perkembangan potensi dan kecerdasan anak di masa-masa selanjutnya (Suyadi, 2010).

Penyampaian informasi mengenai konsep sains dilaksanakan dalam bentuk yang sesuai bagi karakteristik anak usia dini yakni permainan. Hal ini menjadi penting karena sejatinya aktivitas anak dalam keseharian adalah bermain. Whiterington (Anwar, 2005) mengemukakan bahwa bermain memiliki fungsi memudahkan perkembangan kognitif anak sehingga memungkinkan anak 
mempelajari sesuatu dan memecahkan masalah yang dihadapi dari lingkungannya. Bermain juga dapat meningkatkan perkembangan sosial anak. Jelas bahwa setiap kegiatan atau aktivitas yang hendak dirancang bagi anak dalam bentuk bermain atau permainan bermuatan sains.

\section{Keterampilan Sains Anak Usia Dini}

Gagne (Dahar, 1989) mengemukakan bahwa 'dengan mengembangkan keterampilan sains (IPA), anak didik akan dibuat kreatif sehingga mereka akan mampu mempelajari IPA di tingkat yang lebih tinggi dalam waktu yang lebih singkat'. Keterampilan sains yang telah dimiliki anak memungkinkannya untuk memahami sains dengan metode yang lebih sistematis melalui langkah-langkah yang serupa dilakukan oleh para ahli. Oleh karena itu, keterampilan sains yang telah dimiliki oleh anak membentuk sikap ilmiah yang memudahkannya mempelajari konsep sains. Sikap ilmiah inilah yang kelak dapat membangun karakter positif siswa lebih lanjut.

Keterampilan sains dalam bentuk keterampilan proses terdiri dari dua kategori, yakni keterampilan proses sains yang sifatnya empirik dan keterampilan proses sains yang sifatnya analitik. Pertama, keterampilan proses yang sifatnya empirik terdiri dari keterampilan mengamati, mengklasifikasikan, menggunakan angka atau bilangan, dan mengukur. Keterampilan proses yang sifatnya empirik lebih menekankan pada penggunaan indera yang dimiliki oleh anak, baik itu penglihatan, pendengaran, perabaan, penciuman, dan pengecap. Kedua, keterampilan proses yang sifatnya analitik terdiri dari keterampilan mendefinisikan secara operasional, menggunakan hubungan ruang dan waktu, melakukan inferensi, memprediksi, memformulasi hipotesis, menginterpretasikan data, mengendalikan variabel, melakukan eksperimen, dan mengkomunikasikan. Keterampilan proses yang sifatnya analitik lebih melibatkan proses berpikir yang lebih tinggi.

Berdasarkan uraian mengenai keterampilan sains di atas, terdapat beberapa keterampilan sains yang dapat dilatih dan dikembangkan pada anak usia dini, di antaranya mengamati, mengelompokkan, menggunakan angka atau bilangan, memprediksi, melakukan eksperimen, dan mengomunikasikan.

1. Mengamati

Mengamati merupakan kegiatan pencarian informasi dengan memanfaatkan alat indera terkait. Kegiatan mengamati merupakan keterampilan paling mendasar dalam sains. Mengamati pada anak usia dini dapat dilakukan secara visual maupun non visual. Anak dapat mengumpulkan berbagai informasi apapun melalui kegiatan pengamatan, meliputi wujud, bentuk, warna, bau, rasa, dan tekstur benda, bunyi/suara, atau keadaan alamiah lain.

2. Mengklasifikasikan

Mengklasifikasikan merupakan kegiatan pengelompokkan benda berdasarkan karakteristik benda yang teramati. Mengklasifikasikan pada anak usia dini dapat dilakukan melalui kegiatan klasifikasi berdasarkan warna, bentuk, ukuran, dan tekstur benda padat, tumbuh-tumbuhan, bunga-bungaan, hewan, dan objek lain di sekitar. 
3. Menggunakan angka atau bilangan

Angka atau bilangan merupakan dasar dari seluruh keterampilan sains. Angka atau bilangan dipergunakan untuk mengkuantitatifkan hasil pengamatan, menyatakan hasil pengukuran, mengelompokkan benda serta mencatat dan mengkomunikasikan data pengamatan. Menggunakan angka atau bilangan pada anak usia dini dapat dilakukan melalui kegiatan menghitung sederhana bendabenda yang diamati, dan menentukan jumlah benda yang dikelompokkan.

4. Memprediksi

Memprediksi merupakan suatu kegiatan perkiraan yang didasarkan pada pengukuran, pengamatan dan inferensi mengenai hubungan antara variabel terobservasi. Memprediksi bukanlah ramalan yang tanpa dasar. Memprediksi pada anak usia dini dapat dilakukan melalui kegiatan memperkirakan perilaku fisis benda-benda di sekitar anak.

5. Melakukan eksperimen

Melakukan eksperimen merupakan kegiatan percobaan yang melibatkan keterampilan sains dasar dan terintegrasi. Melakukan eksperimen pada anak usia dini dapat dilakukan melalui kegiatan percobaan sederhana menggunakan benda-benda yang ada di sekitar anak dan dikenal olehnya. Kegiatan eksperimen pada anak usia dini perlu dirancang agar aman dan menarik, namun pesan yang terkandung dalam eksperimen itu tersampaikan.

6. Mengomunikasikan

Mengomunikasikan merupakan kegiatan menyampaikan hasil pekerjaan yang melibatkan keterampilan proses dalam bentuk lisan atau tulisan. Mengomunikasikan pada anak usia dini dapat dilakukan pada kegiatan menceritakan kembali apa yang dilakukan oleh anak, termasuk di dalamnya kegiatan mengamati, mengklasifikasikan, membilang, memprediksi dan melakukan percobaan sederhana. Pada kegiatan mengomunikasikan dapat terlihat apakah anak mengetahui apa yang telah dilakukannya dan untuk apa dilakukan.

\section{Fenomena Fisika dalam Mengembangkan Keterampilan Sains Anak Usia Dini}

Sains merupakan sebuah materi ajar yang memang tidak dibelajarkan di TK. Namun demikian, sebagaimana telah diuraikan sebelumnya, bukan berarti anak dilarang mempelajarinya. Untuk membuat pembelajaran sains di TK lebih bermakna dan bersahabat, diperlukan cara pengemasan pembelajaran yang bersifat kontekstual. Sebenarnya, disadari atau tidak, konsep sains telah anak pelajari secara otodidak. Namun, umumnya anak kurang menyadari bahwa yang sedang dipahaminya merupakan konten sains. Beberapa topik-topik sains menurut Wolfinger (Suyanto, 2006) yang dapat dibelajarkan pada anak diantaranya:

1. Mengenal benda padat

Benda padat merupakan benda yang secara struktur lebih kaku dibandingkan wujud lainnya. Benda padat dapat dikenalkan pada anak melalui sifat-sifatnya yang khas, seperti tidak mudah berubah bentuk, cenderung kaku (meskipun ada benda padat yang sifatnya elastis), dan lebih kokoh. Ada banyak contoh benda padat yang dapat ditemukan di sekitar anak, seperti balok atau kubus kayu, 
wadah plastik atau kaca, bola, dan sebagainya. Beberapa benda padat tertentu dapat berubah bentuk bila dipanaskan. Fenomena melelehnya lilin ketika dibakar merupakan salah satu contohnya. Melalui kegiatan bermain dengan benda padat, beberapa keterampilan sains dapat dilatihkan. Misalnya mengamati lilin yang meleleh dan memprediksi lamanya lilin tersebut meleleh, mengklasifikasikan balok atau kubus kayu berdasarkan besarnya, serta menghitung jumlah balok atau kubus kayu, kemudian mengkomunikasikan pada teman-temannya.

2. Mengenal gerak benda

Ada banyak benda yang dapat bergerak di sekitar anak. Namun tidak semuanya dapat bergerak dengan mudah. Benda yang berbentuk bulat (bola atau lingkaran) merupakan benda yang lebih mudah bergerak melalui gerak berputar atau menggelinding, sedangkan kubus kayu lebih sulit bergerak. Fenomena bergeraknya bola pingpong ketika diletakkan pada bidang yang tidak mendatar merupakan salah satu contohnya. Anak dapat dilatihkan untuk mengamati bola yang bergerak pada bidang miring, kemudian memprediksi apakah hal itu terjadi pada kubus kayu, melakukan eksperimen dan mengkomunikasikannya.

3. Mengenal benda cair

Benda cair merupakan benda yang secara struktur kekakuan berada antara benda padat dan gas. Biasanya air merupakan zat yang paling disenangi anak karena sifatnya yang unik. Banyak fenomena fisika yang ditunjukkan oleh air, seperti sifatnya yang dapat menembus benda tertentu tapi tidak dapat menembus benda tertentu yang lain, sifat terapung dan tenggelam, selalu mengikuti bentuk wadahnya, dan selalu berbentuk bola ketika diteteskan. Keterampilan mengamati bentuk air ketika ditempatkan pada wadah yang berbeda, memprediksi jumlahnya ketika dipindahkan dari botol ke piring, melakukan eksperimen, dan mengkomunikasikannya merupakan beberapa keterampilan yang dapat dilatihkan.

4. Mengenal sifat terapung dan tenggelam

Suatu benda akan terapung atau tenggelam dalam air bergantung pada kerapatannya, atau luas permukaannya. Terkadang anak beranggapan bahwa benda yang berukuran kecil cenderung akan terapung, dan sebaliknya benda dengan ukuran besar akan tenggelam. Anak dapat diajak menganati fenomena yang ditunjukkan oleh perilaku gabus dan batu yang ukurannya identik pada air. Anak dapat juga diajak mengamati lilin mainan (plastisin) yang dibentuk bola dan dibuat berbentuk perahu pada air. Selain mengamati, anak juga dapat melakukan klasifikasi, memprediksi, melakukan eksperimen, dan mengomunikasikan apa yang diamatinya.

5. Mengenal warna

Warna merupakan fenomena yang ditunjukkan oleh cahaya dengan panjang gelombang tertentu. Tentu saja anak tidak akan dibelajarkan untuk mengetahui asal usul warna secara alami, melainkan mengajak anak untuk melakukan pencampuran warna, baik untuk warna-warna primer atau warna sekunder. Fenomena fisika yang diperlihatkan oleh munculnya warna ungu ketika anak mencampurkan warna merah dan biru merupakan salah satu hal menarik yang disukai oleh anak. Anak juga dapat dilatihkan keterampilan mengamati, 
mengklasifikasikan, memprediksi, melakukan eksperimen dan mengomunikasikan melalui permainan pencampuran warna.

6. Mengenal benda elastis

Benda elastis merupakan benda padat yang memiliki sifat khas yakni kekakuannya lebih kecil (lebih tidak kaku). Benda semacam ini cenderung tidak mudah rusak ketika terbentur, dan akan melenting jika dijatuhkan. Kelenturan benda elastis seperti bola akan bertambah manakala bagian dalamnya diisi oleh udara. Anak dapat membandingkan perilaku bola yang dalamnya diisi udara dengan bola yang padat ketika dijatuhkan. Melalui penggunaan benda elastis, anak dapat dilatihkan keterampilan mengklasifikasikan, memprediksi, melakukan eksperimen, dan mengomunikasikan.

7. Mengenal udara

Udara merupakan zat yang secara struktur paling tidak kaku. Udara tersusun dari partikel-partikel yang saling renggang dan acak. Udara tidak nampak, sehingga sulit untuk dikenalkan. Namun demikian beberapa fenomena fisika terkait kehadiran udara dapat dikenalkan pada anak. Misalnya ketika kita memasukkan udara dalam balon gas, udara akan memperlihatkan sifat-sifatnya seperti memiliki tekanan (dapat dikompresi; balon akan melesat jika ikatannya dibuka), memiliki berat (bila kita gantungkan pada neraca). Anak mengenali udara sebagai zat yang dapat menerbangkan layang-layang. Anak dapat mengamati perilaku udara ketika dalam wadah, dan dalam tempat tertentu, memprediksi sifat-sifatnya, bereksperimen dengan gas tertentu (seperti balon gas), dan mengomunikasikannya.

8. Mengenal bayang-bayang

Bayang-bayang merupakan fenomena fisika yang hanya akan terbentuk jika ada sumber cahaya. Terkadang melalui cerita sehari-hari, bayang-bayang sering dikaitkan dengan hal-hal yang membuat anak takut. Melalui kegiatan yang melibatkan cahaya dan benda tidak tembus cahaya (opaque), kita dapat mengenalkan adanya bayang-bayang benda. Kita juga dapat menggunakan benda transparan untuk menunjukkan bahwa bayangan hanya terbentuk bila cahaya mengenai benda opaque. Anak dapat dilatihkan untuk mengamati, memprediksi, melakukan eksperimen, dan mengkomunikasikan benda apa yang dapat membentuk bayang-bayang dan benda apa yang tidak dapat membentuk bayang-bayang bila dikenai cahaya.

9. Mengenal neraca

Neraca atau timbangan biasanya digunakan untuk mengenalkan konsep berat dan konsep kesetimbangan pada anak serta fenomena fisika yang ditimbulkan oleh benda yang memiliki kerapatan berbeda. Anak dapat melakukan pengamatan ketika meletakkan dua buah benda yang sama bentuk dan ukurannya (misalnya stip penghapus) pada masing-masing lengan neraca, kemudian memprediksi yang akan terjadi bila stip penghapus pada salah satu lengan neraca diganti dengan batu atau besi yang ukurannya lebih kecil.

10. Mengenal api

Kegiatan ini lebih ditekankan pada pengaruh api pada benda yang terbakar, bukan mengenal api semata. Kegiatan ini mutlak memerlukan pengawasan oleh 
guru secara langsung, karena api bukan sesuatu yang dapat dipelajari secara mandiri. Melalui kegiatan mengenal api, anak dapat mengamati benda-benda yang dapat terbakar dan benda yang tidak dapat terbakar, mengklasifikasikan benda yang mudah terbakar dan yang sulit terbakar, dan mengomunikasikannya.

11. Mengenal es

Es merupakan wujud padat dari air. Akan tetapi umumnya anak mengenal es sebagai sesuatu yang berbeda dari air. Melalui kegiatan percobaan, anak dapat melakukan eksperimen sederhana dan pengamatan mengenai perilaku es yang mencair (meleleh) ketika dipanaskan, memprediksi berapa lama es mencair, dan mengomunikasikannya.

12. Mengenal bunyi

Bunyi merupakan sesuatu yang dihasilkan oleh benda yang bergetar. Getaran tersebut merambat dari benda yang bergetar melalui udara, dan benda lain yang dilaluinya. Fenomena perambatan bunyi dapat dikenalkan pada anak menggunakan media sederhana, seperti selang panjang (untuk menunjukkan bunyi merambat melalui udara), corong air (untuk menunjukkan bunyi merambat melalui air) atau kaleng yang dihubungkan dengan tali (untuk menunjukkan bunyi merambat melalui zat padat). Anak dapat dilatihkan keterampilan mengamati, melakukan eksperimen dan mengomunikasikannya.

13. Mengenal benda magnet

Magnet merupakan benda yang dapat menarik benda lain yang terbuat dari bahan mengandung besi. Meskipun anak mungkin beranggapan bahwa magnet merupakan benda ajaib yang dapat menarik benda lain, namun kita dapat mengenalkannya melalui fenomena yang ditunjukkannya. Anak dapat dilatihkan keterampilan melakukan eksperimen, memprediksi benda yang dapat ditarik magnet dan benda yang tidak dapat ditarik magnet, serta mengklasifikasikan dan mengomunikasikannya.

\section{PENUTUP}

Sains merupakan suatu konsep yang perlu dibelajarkan pada anak sejak dini. Pengenalan sains pada anak melalui metode dan pendekatan yang sesuai dapat membantu anak untuk mempelajari sains secara lebih ringan namun bermakna. Fenomena fisika merupakan salah satu fakta alamiah yang dapat digunakan untuk membelajarkan sains pada anak. Lebih lanjut pembelajaran sains melalui fenomena fisika dapat melatih dan mengembangkan keterampilan sains anak sehingga berkontribusi pada daya nalar anak kelak di kemudian hari. Beberapa keterampilan sains yang dapat dilatihkan pada anak di antaranya keterampilan mengamati, mengelompokkan, menggunakan angka atau bilangan (menghitung), memprediksi, melakukan eksperimen, dan mengomunikasikan. Terdapat beberapa topik sains yang dapat dikenalkan melalui pengamatan fenomena fisika yang terjadi di sekitar anak, seperti mengenal benda padat, mengenal gerak benda, mengenal benda cair, mengenal sifat terapung dan tenggelam, mengenal warna, mengenal benda elastis, mengenal udara, mengenal bayang-bayang, mengenal neraca, mengenal api, mengenal es, mengenal bunyi, serta mengenal benda magnet. Melalui pengamatan 
fenomena fisika, diharapkan anak akan mengenali konten dan konsep sains secara lebih ringan namun bermakna.

\section{DAFTAR PUSTAKA}

Anwar, D. Y. (2005). Mengenalkan Sains pada Anak Usia Dini. [Online]. Tersedia: http://www.suaramerdeka.com/harian/0511/07/ragam03.htm (5 Maret 2014)

Dahar, R.W. (1989). Teori-teori Belajar. Jakarta: Erlangga.

Departemen Pendidikan Nasional. (2008). Sistem Pendidikan Nasional (SISDIKNAS). Bandung: Nuansa Aulia

Liliasari. (1996). Beberapa pola berpikir dalam pembentukan pengetahuan kimia oleh siswa SMA. Disertasi PPS IKIP Bandung: Tidak diterbitkan.

Suyadi. (2010). Psikologi Belajar Pendidikan Anak Usia Dini. Yogyakarta: Pedagogia

Suyanto, S. (2006). Pengenalan Sains untuk Anak TK dengan Pendekatan "Open Inquiry". [Online] Tersedia: staff.uny.ac.idsitesdefaultfiles131930139journal\%20 PENGENALAN\%20SAINS\%20UNTUK\%20ANAK\%20TK.pdf. (5 Maret 2014) 